Reeser, P., Sutton, W., Ganley, B., Williams, N., and Hansen, E. 2015. Phytophthora pluvialis. Forest Phytophthoras 5(1). doi: $10.5399 / \mathrm{osu} / \mathrm{fp} \cdot 5 \cdot 1.3745$.

\title{
Phytophthora pluvialis
}

\section{Overview}

Phytophthora pluvialis Reeser, Sutton, and E. Hansen was first discovered in streams, soil, and raintraps in Curry County, Oregon, USA, in areas dominated by native forest of mixed tanoak and Douglas-fir (Reeser et al., 2013). On rare occasions it was isolated from lesions on tanoak bark or twigs, but was only weakly pathogenic when inoculated into tanoak stems. In New Zealand, Phytophthora pluvialis was found to cause red needle cast on radiata pine (Dick et al., 2014). In Oregon the species is now associated with Douglas-fir, and experimentally has been shown to cause needle cast and twig cankers on seedling trees, both artificially inoculated and exposed beneath the canopy of Douglas-fir plantations (Hansen et al., 2014). The pathogen has not been associated with canker formation or infection of the harvested stem of radiata pine (Hood et al., 2014).

\section{Morphology}

Sporangia (average 53-67 $\mu \mathrm{m}$ by 39-45 $\mu \mathrm{m}$ ) formed in water, ovoid or slightly irregular (occasionally bifurcate), semi-papillate, terminal or sub-terminal on simple or sympodial sporangiophores. Sporangia are partially caducous with variable, medium length $(5-22 \mu \mathrm{m})$ pedicels (Fig. 1). Hyphal swellings formed in water are globose and intercalary with radiating hyphae forming loose networks. Hyphal swellings formed in agar are variable (Fig. 2). Oogonia (average 27 $\mu \mathrm{m}$ to $34 \mu \mathrm{m}$ ), formed in single agar culture, globose, smooth, terminal with amphigynous antheridia. Oospores (average ca. 27-29 $\mu \mathrm{m}$ ), globose, aplerotic (Fig. 3).

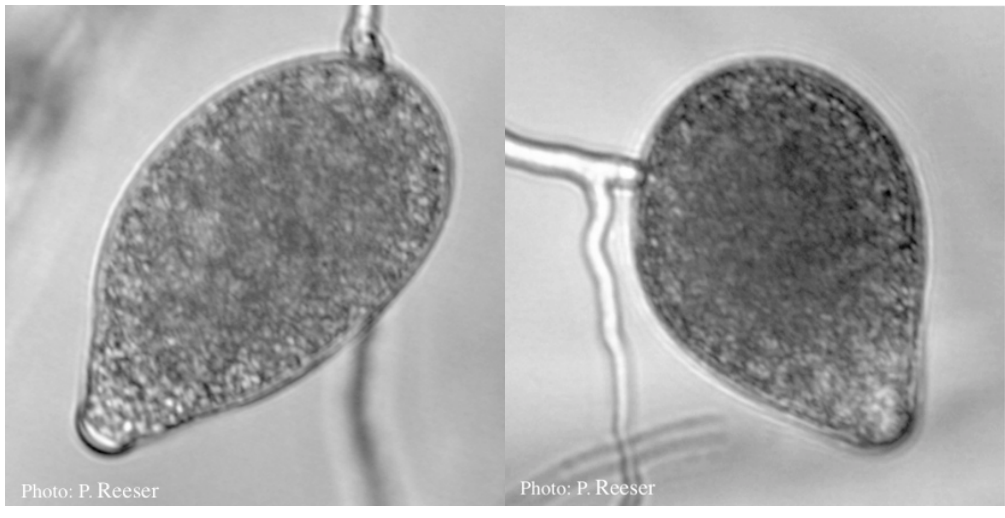

Figure 1. Sporangia showing typical ovoid shape and semi-papillate condition.



Figure 2. Hyphal swellings on agar (left) and in water (right).

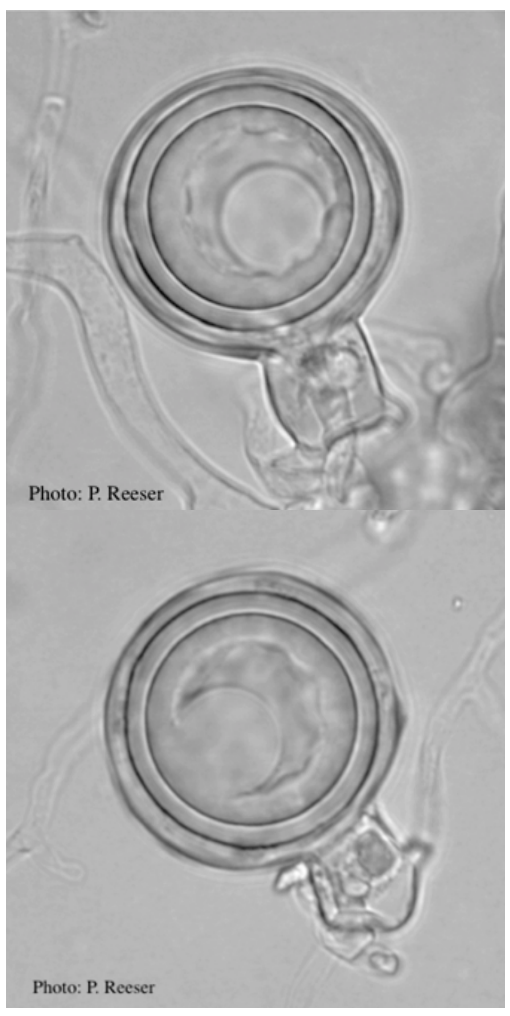

Figure 3. Oogonia and oospores with amphigynous antheridia. 


\section{Genetics}

Phytophthora pluvialis resides in ITS Clade 3 (Cooke et al., 2000) along with P. ilicis Buddenhagen \& Young, P. nemorosa E.M. Hansen \& Reeser, P. pseudosyringae T. Jung \& Delatour, and $P$. psychrophila T. Jung \& E.M. Hansen. It is readily distinguished by ITS DNA sequence from related species in Clade 3 (Fig. 4).

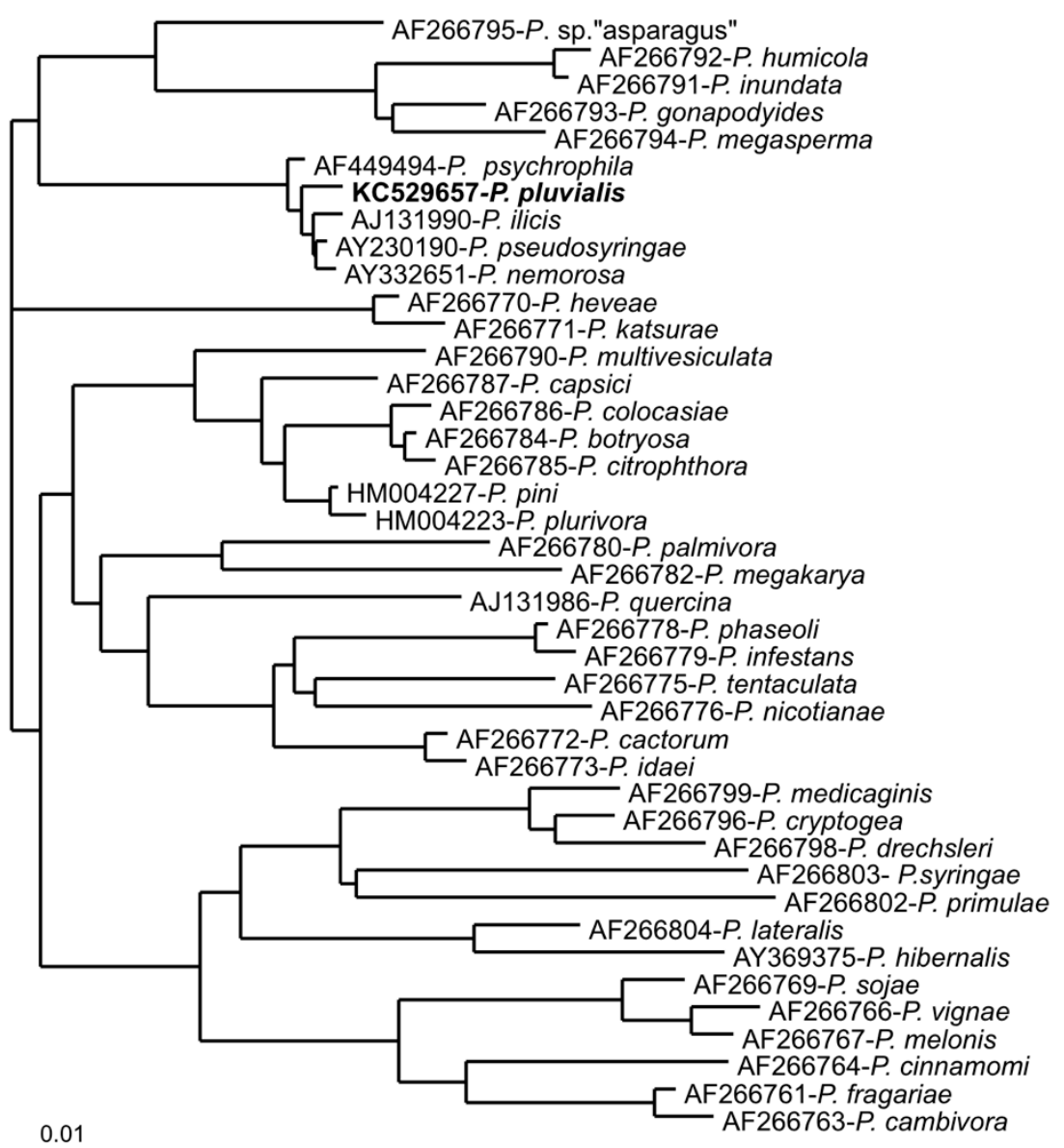

Figure 4. Phylogenetic relations based on rDNA-ITS sequences (Reeser et al., 2013).

\section{Growth in culture}

The colony pattern on carrot agar is angular and petaloid, with hyphae appressed (Fig. 5). Radial growth rate on carrot agar is about $1.2-1.4$ $\mathrm{mm} / \mathrm{d}$ at $15^{\circ} \mathrm{C}$. Temperature

optimum was ca. $15^{\circ} \mathrm{C}$, min. $<5^{\circ} \mathrm{C}$, $\max$. ca. $25^{\circ} \mathrm{C}$.

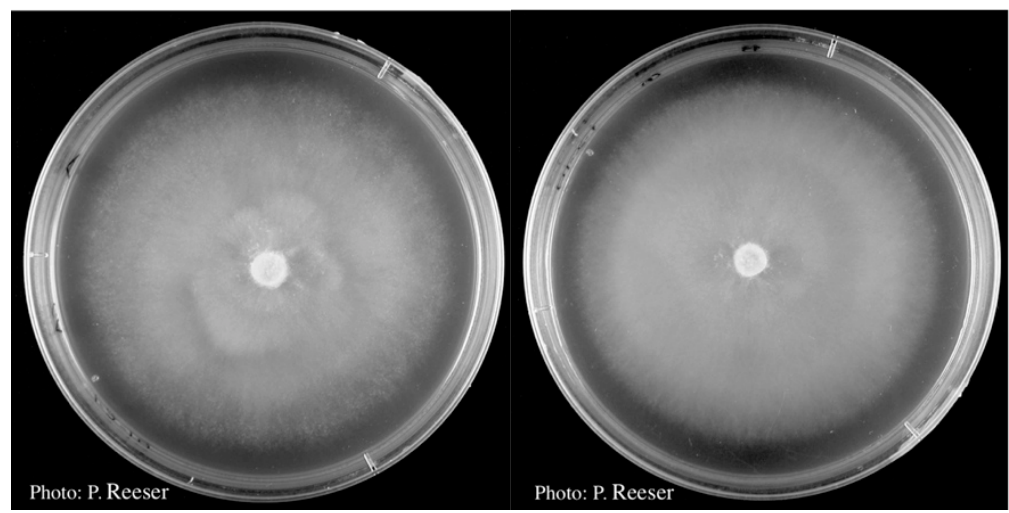

Figure 5. Colony morphology of two different isolates on carrot agar at 20 days. 


\section{Distinguishing characteristics for identification}

P. pluvialis is most readily recognized by its semi-papillate sporangia, amphigynous antheridia, and distinctive hyphal swellings formed both in agar and in water. It is most similar to P. nemorosa, but growth rate of $P$. pluvialis at optimum temperature is much slower.

\section{Impacts in the Forest}

P. pluvialis appears to be part of the native forest mycota of western Oregon. The impact of its association with Douglas-fir in Oregon has yet to be elucidated, but observations suggest there could be an association with lower canopy needle loss in dense stands located in humid areas. P. pluvialis might reduce the success of natural regeneration of Douglas-fir under dense stands. In New Zealand the impact on plantation radiata pine and Douglas-fir is of concern to forest growers in high diseaseprone areas due to growth loss following needle cast (Ganley et al., 2014).

\section{Forest and Wildland Hosts and Symptoms}

Needle infection of radiata pine is characterized by the production of a resinous band which extends to pale-olive or khaki colored lesions (Figs. 6-7) which closely resemble those reported for $P$.

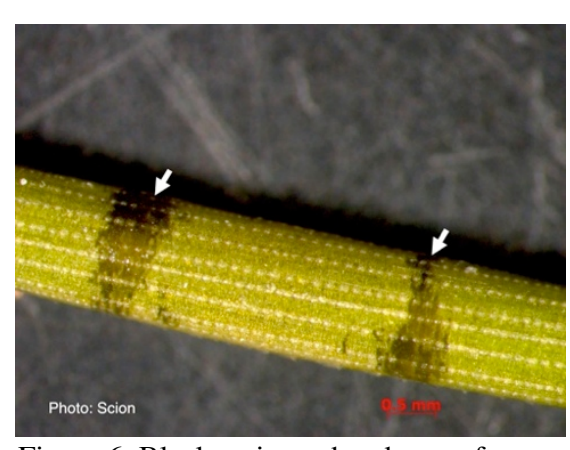

Figure 6. Black resinous bands are often formed on radiata pine needles following infection by $P$. pluvialis.

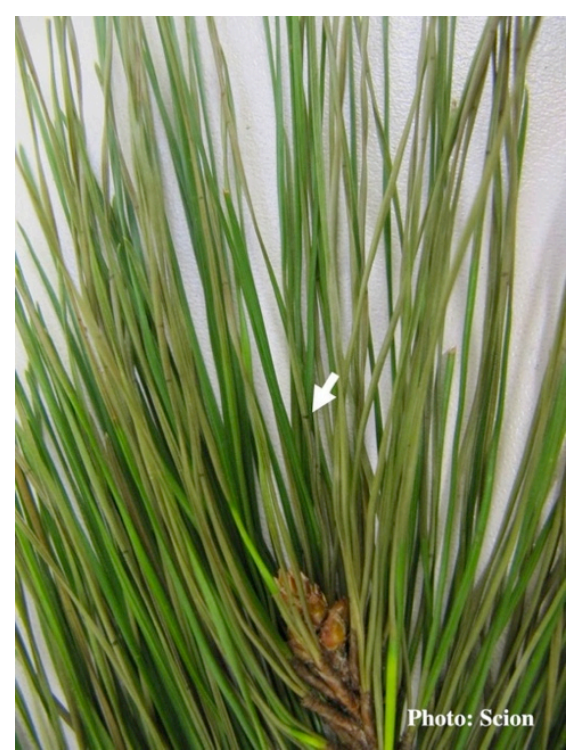

Figure 7. On radiata pine, faded olive- or khaki- colored lesions are observed predominantly at the base of the needles, but also appear anywhere along the needle. Arrow shows a resinous band within the extended olive lesion. pinifolia infection of radiata pine in association with daño foliar del pino (DFP) in Chile (Durán et al., 2008). For P. pluvialis infection, lesions are most commonly observed in the basal portion of the needle near the fascicle sheath (Fig. 8-9). Needle infection of Douglas-fir results in chlorotic needle mottling (Fig. 10) and canker development in seedlings (Hansen et al., 2014). Clusters of sporangia form on needles of Douglas-fir and radiata pine (Fig. 11). In both species, infection is followed by premature casting of the needle which in Douglas-fir often happens while the needles are still green. The term red needle cast reflects the expression of red needles in the lower half of the canopy prior to needle cast, leaving a sparse internal canopy in both Douglas-fir (Fig. 12) and radiata pine (Fig. 13) when disease levels are severe. P. pluvialis infection may be distinguished from other similar needle diseases by the loss of all cohorts of needles, production of olive, resinous bands in the absence of fruiting bodies, and production of healthy needles with the new flush (Fig. 14). To view more images, see http://forestphytophthoras.org/gallery.

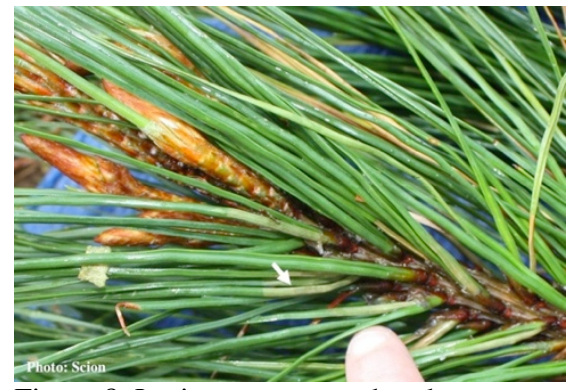

Figure 8. Lesions are more abundant at the base of radiata pine needles where moisture is retained between the 3-5 needles within the fascicle.



Figure 9. Typical red needle cast symptoms along a twig. Lesions begin at the base of the needle which subsequently turns brown and is cast from the twig. 


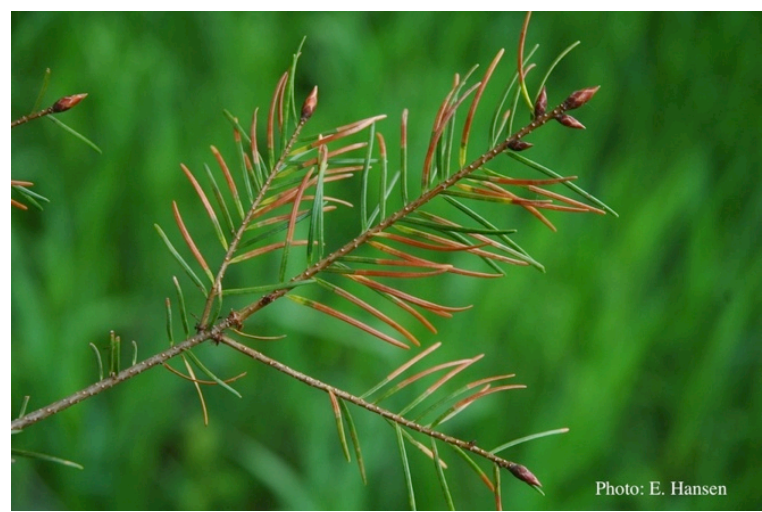

Figure 10. Symptoms of red needle cast on Douglas-fir needles.

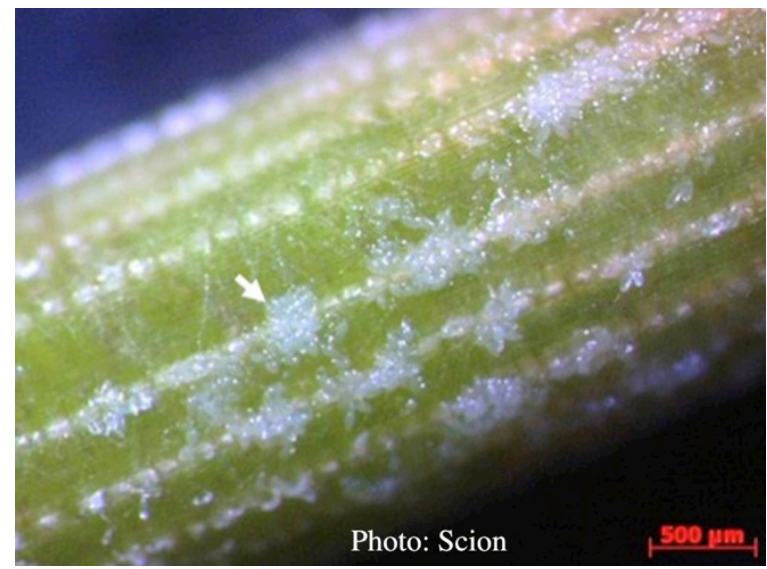

Figure 11. Clusters of sporangia emerge from stomata of an infected radiata pine needle.

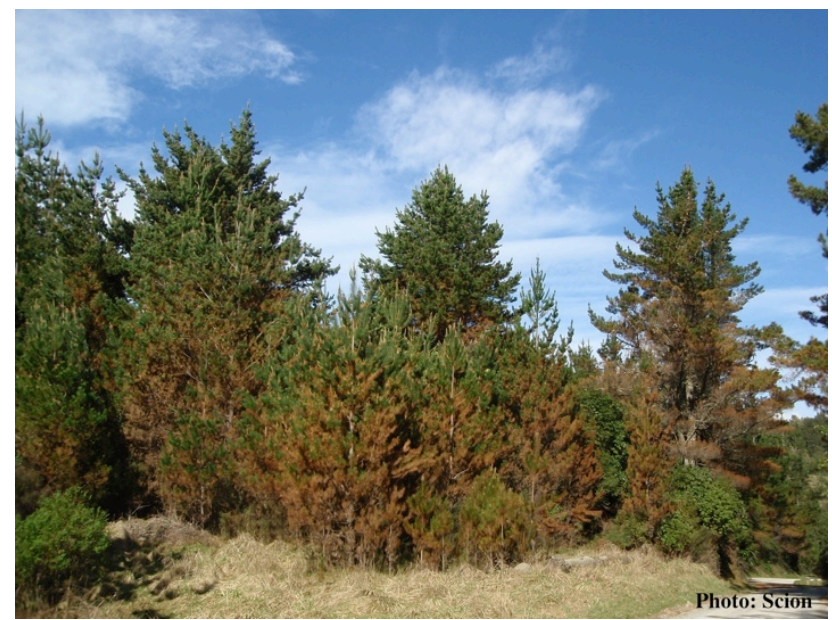

Figure 13. A stand of radiata pine trees affected by red needle cast disease. Note the reddish appearance of affected trees prior to needle drop.

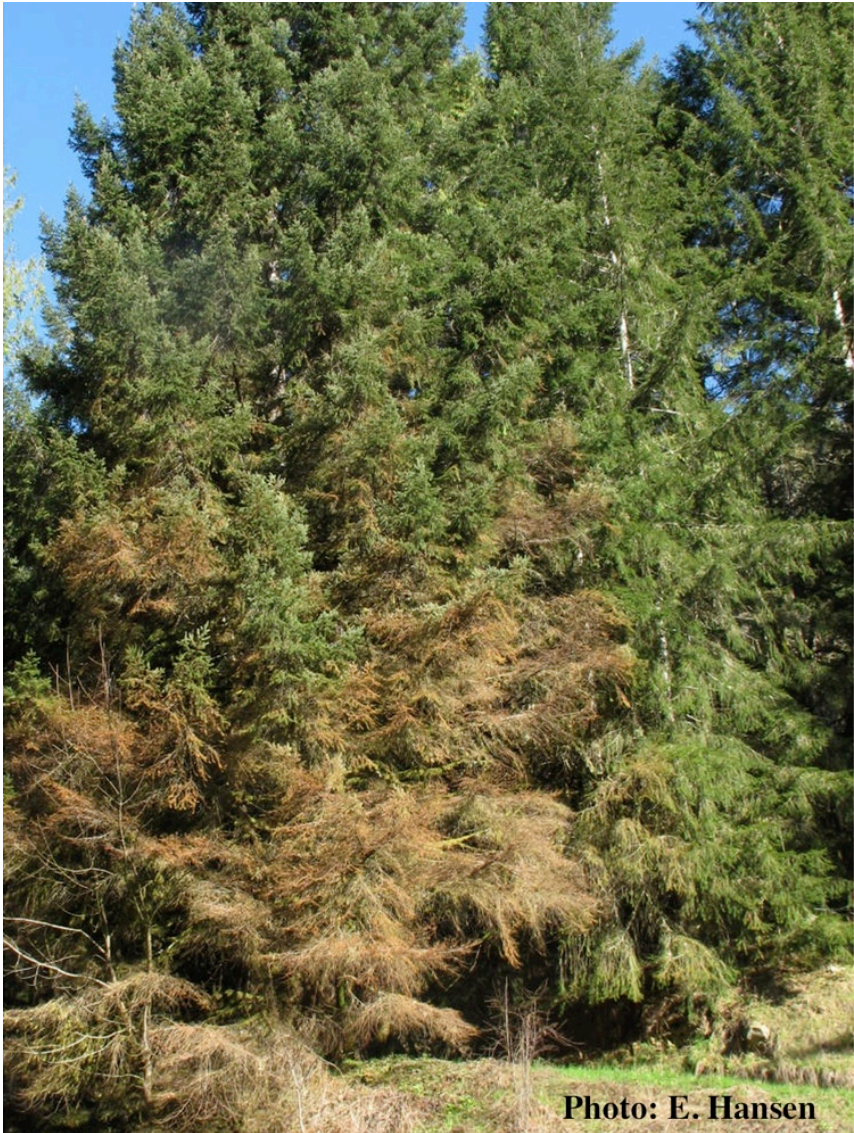

Fig. 12. Red needle cast symptoms on Douglas-fir in western Oregon, 2015.

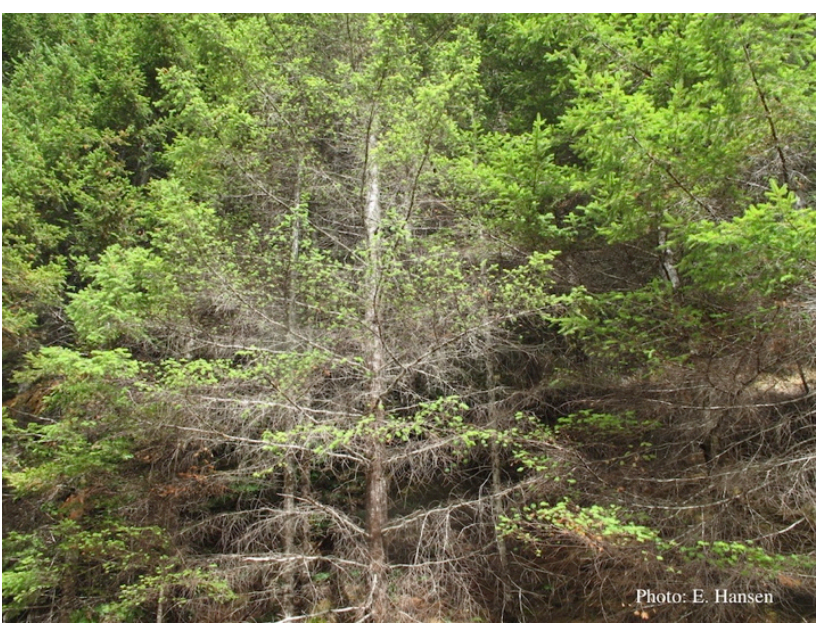

Fig. 14. Tufted appearance of new growth from surviving buds on Douglas-fir, one year after defoliation.

\begin{tabular}{|c|c|c|c|c|}
\hline Host Latin Name & $\begin{array}{l}\text { Host Common } \\
\text { Name }\end{array}$ & Symptoms & Habitat & Region \\
\hline $\begin{array}{l}\text { Notholithocarpus } \\
\text { densiflorus }\end{array}$ & tanoak & Canker & Forest & USA- Oregon \\
\hline $\begin{array}{l}\text { Pseudotsuga } \\
\text { menziesii }\end{array}$ & Douglas-fir & $\begin{array}{l}\text { Stem canker, } \\
\text { needle cast }\end{array}$ & Plantation forest & USA- Oregon \\
\hline $\begin{array}{l}\text { Pseudotsuga } \\
\text { menziesii }\end{array}$ & Douglas-fir & Needle cast & Exotic plantation & New Zealand \\
\hline Pinus radiata & radiata pine & Needle cast & Exotic plantation & New Zealand \\
\hline
\end{tabular}


Breeding for resistance is a long-term option for management of red needle cast in radiata pine plantations. Field and laboratory screening have shown that resistance to needle loss due to red needle cast is heritable. Screening is underway to identify resistance within current radiata pine breeding lines in use in New Zealand (Dungey et al., 2014). Phosphoric acid (phosphite) and copper have both shown promise for the control of $P$. pluvialis within plantation systems, but are yet to be applied operationally within New Zealand forest systems (Ganley et al., 2014;

Rolando et al., 2014).

\section{References}

Cooke, D. E. L., Drenth, A., Duncan, J. M., Wagels, G., and Brasier, C. M. 2000. A molecular phylogeny of Phytophthora and related Oomycetes. Fungal Genet Biol. 30:17-32. http://dx.doi.org/10.1006/fgbi.2000.1202

Dick, M., Williams, N., Bader, M., Gardner, J., and Bulman, L. 2014. Pathogenicity of Phytophthora pluvialis to Pinus radiata and its relation with red needle cast disease in New Zealand. New Zeal. J. For. Sci. 44:6. http://dx.doi.org/10.1186/s40490-014-0006-7

Dungey, H. S., Williams, N. M., Low, C. B., and Stovold, G. T. 2014. First evidence of genetic-based tolerance to red needle cast caused by Phytophthora pluvialis in radiata pine. New Zeal. J. For. Sci. 44:31. http://dx.doi.org/10.1186/s40490-014-0028-1

Durán, A., Gryzenhout, M., Slippers, B., Ahumada, R., Rotella, A., Flores, F., Wingfield, B. D., and Wingfield, M. J. 2008. Phytophthora pinifolia sp. nov. associated with a serious needle disease of Pinus radiata in Chile. Plant Pathol. 57(4):715-727. http://dx.doi.org/10.1111/i.1365-3059.2008.01893.x

Ganley, R. J., Williams, N. M., Rolando, C. A., Hood, I. A., Dungey, H. S., Beets, P. N., and Bulman, L. S. 2014. Management of red needle cast, caused by Phytophthora pluvialis, a new disease of radiata pine in New Zealand. N. Z. Plant Protect.-SE 67:48-53. http://www.nzpps.org/journał67/nzpp_670480.pdf

Hansen, E. M., Reeser, P., Sutton, W., Gardner, J., and Williams, N. 2015. First report of Phytophthora pluvialis causing needle loss and shoot dieback on Douglas-fir in Oregon and New Zealand Plant Dis. 99(5):727. http://apsjournals.apsnet.org/doi/10.1094/PDIS-09-14-0943-PDN

Hood, I. A., Williams, N. M, Dick, M. A., Arhipova, N., Kimberley, M. O., Scott, P. M., and Gardner, J. F. 2014. Decline in vitality of propagules of Phytophthora pluvialis and Phytophthora kernoviae and their inability to contaminate or colonise bark and sapwood in Pinus radiata export log simulation studies. New Zeal. J. For. Sci. 44(7):13 pp. http://dx.doi.org/10.1186/s40490-014-0007-6

Reeser, P., Sutton, W., and Hansen, E. M. 2013. Phytophthora pluvialis, a new species from mixed tanoak-Douglasfir forests of western Oregon, U.S.A. North American Fungi. 8(7):1-8. http://dx.doi.org/10.2509/naf2013.008.007

Rolando, C., Gaskin, R., Horgan, D., Williams, N., and Bader, M. K. 2014. The use of adjuvants to improve uptake of phosphorous acid applied to Pinus radiata needles for control of foliar Phytophthora diseases. New Zeal. J. For. Sci. 44(1):1-7. http://dx.doi.org/10.1186/s40490-014-0008-5

Scott, P., and Williams, N. 2014. Phytophthora diseases in New Zealand forests. New Zeal. J. For. 59(2):14-21. http://www.nzjf.org/abstract.php?volume_issue=i59_2\&first_page $=14$ 